\title{
ENHANCED SELENIUM CONTENT IN SWEET BASIL (OCIMUM BASILICUM L.) BY FOLIAR FERTILIZATION
}

\author{
Barbara HAWRYLAK-NOWAK \\ Department of Plant Physiology, University of Life Sciences of Lublin \\ Akademicka 15, 20-950 Lublin, Poland
}

Received: April 11, 2008; Accepted: June 22, 2008

\begin{abstract}
Summary
Selenium has been recognized as an essential trace element for animals and humans. Although it has not been confirmed to be an essential micronutrient in plant tissues, plants play a unique role in recycling and delivering selenium from the soil to food chain. The aim of this study was to investigate the effect of foliar application of different selenium concentrations $(1-50 \mathrm{mg}$ $\mathrm{Se} \cdot \mathrm{dm}^{-3}$ ) on the growth, content of chloroplast pigments, anthocyanins, total phenolic compounds and selenium, as well as lipid peroxidation in sweet basil (Ocimum basilicum L.) seedlings. The total selenium concentration in the shoots increased with increasing selenium supplementation. It has been found that the level of selenium fertilization had no significant effect on the content of chloroplast pigments, but it increased the synthesis of anthocyanin and phenolic compounds. MDA (malonodialdehyde) content in sweet basil leaves decreased with increasing selenium treatments. The obtained results suggest that it is possible to enhance selenium content in sweet basil plants by foliar fertilization, making it a rich source of dietary selenium and useful as a raw material for enriched food products.
\end{abstract}

key words: sweet basil, selenium, foliar application

\section{INTRODUCTION}

Selenium is a micronutrient that is necessary for an appropriate human's and animal's organisms functioning, and its deficiency as associated with a variety of diseases and disturbances called as hyposelenosis. Numerous epidemiological studies confirm that selenium deficit in a diet increases the frequency of heart diseases appearance, leads to disturbances in thyroid functions, weakens the immune system, contributes to cancer occurrence, and decreases the organism's resistance to stress factors. Therefore, the selenocystein as a constituent of selenoproteins with an important biological function, is considered as $21^{\text {st }}$ proteinogenic amino acid (Birringer et al. 2002, Rayman 2000). The "selenium map" of Europe published by Giessel-Nielsen et al. (1984) indicates

Corresponding author: e-mail: bhawrylak@yahoo.com

(c) Copyright by RIVC 
that there is a deficit of this element in a diet on major part of the continent, which results from low selenium content in soils, and in consequence, in plants, and further links of the food chain.

Diet is a main selenium source for humans and animals. Selenium level in fodders and food produced in Poland, only in small number of cases covers daily requirements for the microelement. It is thought that hyposelenosis with varied intensities occur on about $77 \%$ of Poland (Dębski et al. 2001). Introducing the food abundant in easily available selenium forms is a natural way that can ensure an appropriate selenium status. Meat and fish are relatively rich in selenium, mainly in a form of selenocystein. However, it has been found that selenocystein is characterized quite poor availability in digestive tract. Despite that fruits and vegetables contain much less selenium than animal-origin products, its chemical form within plants - selenomethionin - is much better available than selenocystein (Poggi et al. 2000).

At present, selenium is not counted to elements essential for a proper growth and development of higher plants; however, it is quite easily taken and accumulated by plants in various organs. Furthermore, plant organisms are the main link that combines selenium turnover in nature: when taking the inorganic selenium from a soil and converting it into organic compounds, plants themselves become its source for people and animals (Terry et al. 2000, Ellis \& Salt 2003). In many countries, where selenium deficit was recognized, it is introduced into the food chain by means of soil fertilization of vegetables and root crops with the element's salts as an addition into the mineral fertilizers. Unfortunately, utility plants enriched in selenium have not been cultivated in Poland yet. Extremely small number of selenium-containing fertilizers can be found on Polish markets, which mainly results from poor receiver's interests. Moreover, varied soil environmental conditions may greatly reduce its availability by plants. Thus, foliar application of selenium for plants gets more and more important as the most efficient, economic, and safe method for enriching the plant biomass in selenium (Borkowski \& Dyki 2007).

Sweet basil (Ocimum basilicum L.) is an annual herb that belongs to Lamiaceae family. Its aromatic leaves and shoots, both fresh and dried herb, are mainly used as a spice. Basil herb has also found its application in cosmetics and medicine (De Masi et al. 2005).

The present research has been aimed at evaluating the influence of foliar application of varied selenium concentrations on selected physiological factors and selenium content in basil plants.

\section{MATERIAL AND METHODS}

Experiments were carried out in the laboratory of Plant Physiology Department, University of Life Sciences of Lublin, in the years 2006-2007. Seeds of basil (Ocimum basilicum L.) achieved from the Seed Center in Lublin were sown onto the wet quartz sand. Then, 2-weeks-old seedlings were set into the pots (4 plants each) containing $250 \mathrm{~g}$ of garden soil (pH 5.5-6.5). After 7 days, 2 
healthy uniform seedlings were remained in every pot. After the following 3 weeks of plant growth, foliar spraying with water solution of selenium salt was applied. The solution contained selenium in a form of sodium selenate $\left(\mathrm{Na}_{2} \mathrm{SeO}_{4}\right)$ at concentrations of $1,3,5,10,20$, or $50 \mathrm{mg} \mathrm{Se} \cdot \mathrm{dm}^{-3}$. Control plants were treated with distilled water. The vegetation was performed in vegetation chamber (model MRL 350HT, Sanyo) under conditions of controlled photosynthetic photon flux density within active photosynthetic range $\left(270 \mu \mathrm{mol} \cdot \mathrm{m}^{-2} \cdot \mathrm{s}^{-1}\right)$, at photoperiod $14 / 10 \mathrm{~h}$, temperature $25 / 20^{\circ} \mathrm{C}$ (day/night), and relative humidity $75 \%$.

Seven days after spraying, the plant material was subjected to chemical analyses. Contents of assimilation pigments (chlorophyll $a$ and $b$ as well as carotenoids) were determined in fresh matter by means of Lichtenthaler \& Wellburn (1983) method. Pigments were extracted from tissues by homogenizing in $80 \%$ acetone. The absorbance was read at $663 \mathrm{~nm}$ wavelength for chlorophyll $a, 645 \mathrm{~nm}$ for chlorophyll $b$, and $470 \mathrm{~nm}$ for carotenoids.

Anthocyanin concentrations were determined applying modified Harborne technique (Martinez \& Favret 1990). Anthocyanin pigments were extracted from leaves by maceration with methanol plus $\mathrm{HCl}$ mixture. Measurements of absorbance were made at $527 \mathrm{~nm}$ wavelength, which corresponded to absorbance maximum for cyjanidino-3-monoglucoside. Due to the presence of accompanying chlorophyll (at amounts exceeding anthocyanin contents) in achieved extract, the second reading was made at $652 \mathrm{~nm}$ wavelength. Concentration of anthocyanins was calculated using molar absorbance coefficient for cyjanidino3-monoglucoside and taking into account the molecular weight of particular anthocyanin and sample dilution factor (Cheng \& Breen 1991).

Contents of total phenolic compounds were determined on a base of colorimetry (Swain \& Hillis 1959). Fresh matter was flooded with $96 \%$ ethanol and boiled under reflux cooler then samples were cooled and mixed. Achieved homogenized matter was quantitatively transferred onto the filter paper and precipitation was washed out using $80 \%$ ethanol. Aliquots of $0.5 \mathrm{~cm}^{3} 25 \%$ $\mathrm{Na}_{2} \mathrm{CO}_{3}$ and $0.25 \mathrm{~cm}^{3}$ Folin's agent diluted with water at 1:1 ratio were added into $5 \mathrm{~cm}^{3}$ of ethanol extract. After 15 minutes, absorbance at $760 \mathrm{~nm}$ wavelength was read. Phenolic compounds contents were calculated on a basis of calibration curve made for chlorogenic acid as a standard.

Content of malonodialdehyde (MDA) formed in reacting mixture informs on the level of lipid peroxidation (Boominathan \& Doran 2002). In order to determine the MDA content, tissues were homogenized in $0.1 \%$ trichloroacetic acid (TCA) solution. Achieved preparation was centrifuged and $4 \mathrm{~cm}^{3}$ of $20 \%$ TCA containing $0.5 \%$ of thiobarbituric acid (TBA) were added into $1 \mathrm{~cm}^{3}$ of achieved supernatant. Mixture was then heated to $95^{\circ} \mathrm{C}$ for 30 min., quickly cooled and re-centrifuged. The absorbance of achieved solution was measured at $532 \mathrm{~nm}$ wavelength. Content of MDA was calculated on a base of calibration curve for 1,1,3,3-tetraetoxopropane as a standard.

At the end of analyses, shoots were cut off from the roots, washed out, and dried at $105^{\circ} \mathrm{C}$ till constant weight, which allowed for evaluating basil's yielding. Achieved plant material was subjected to chemical analysis to determine selenium 
contents: material was preliminarily digested in mixture of $\mathrm{HNO}_{3}: \mathrm{HClO}_{4}(4: 1$ $\mathrm{v} / \mathrm{v}$ ) and heated to $210^{\circ} \mathrm{C}$. Total selenium content was determined by means of AAS with hydride-generation system (HGAAS) (Lloyd et al. 1982).

The statistical design was completely randomized and the experiment consisted of five replications per each treatment plus tree independent replications at a time. Data were tested using analysis of variance (ANOVA) and significantly different mean values for selenium treatments were separated applying Tukey test. Differences at $\mathrm{P} \leq 0.05$ were considered as statistically significant.

\section{RESULTS}

Achieved results indicate that foliar application of selenium at the amounts of $1-5 \mathrm{mg} \mathrm{dm}^{-3}$ did not cause significant changes in overground parts yielding of sweet basil plants. Selenium applied at $10-50 \mathrm{mg} \cdot \mathrm{dm}^{-3}$ concentrations contributed to $25-35 \%$ increase of shoot dry matter as compared to the control (Table 1). Contents of chlorophylls $a$ and $b$ as well as carotenoids did not significantly oscillate within the range of applied selenium concentrations. Foliar selenium application at doses of $10-50 \mathrm{mg} \cdot \mathrm{dm}^{-3}$ apparently influenced on anthocyanins levels in basil's leaves. Plants sprayed with $10 \mathrm{mg} \mathrm{Se} \cdot \mathrm{dm}^{-3}$ solution contained by $73 \%$ more anthocyanin pigments in comparison to control, while the increase of selenium concentration in the solution up to 20 and $50 \mathrm{mg} \cdot \mathrm{dm}^{-3}$ caused 2.5 -fold and 3-fold increased elevation of anthocyanins contents in leaves, respectively (Table 1).

Table 1. Effect of selenium foliar application on dry weight yield, content of pigments and total phenolic compounds in leaves of sweet basil

\begin{tabular}{ccccccc}
\hline \multirow{2}{*}{$\begin{array}{c}\text { Se } \\
\text { concentration } \\
\left(\mathrm{mg} \cdot \mathrm{dm}^{-3}\right)\end{array}$} & $\begin{array}{c}\text { Plant DW } \\
\text { (g per pot) }\end{array}$ & $\begin{array}{c}\text { Chloro- } \\
\text { phyll a }\end{array}$ & $\begin{array}{c}\text { Chloro- } \\
\text { phyll b }\end{array}$ & $\begin{array}{c}\text { Carote- } \\
\text { noids }\end{array}$ & $\begin{array}{c}\text { Antho- } \\
\text { cyanins }\end{array}$ & $\begin{array}{c}\text { Total phenolic } \\
\text { content } \\
\text { (mg chlorogenic } \\
\text { acid equivalent } \\
\left.100 \mathrm{~g}^{-1} \mathrm{FW}\right)\end{array}$ \\
\hline 0, control & $1.06 \mathrm{a}$ & 1.18 & 0.28 & 0.38 & $0.022 \mathrm{a}$ & $857 \mathrm{a}$ \\
1 & $1.23 \mathrm{ab}$ & 1.02 & 0.27 & 0.33 & $0.021 \mathrm{a}$ & $802 \mathrm{a}$ \\
3 & $1.18 \mathrm{ab}$ & 1.09 & 0.31 & 0.37 & $0.024 \mathrm{a}$ & $1003 \mathrm{~b}$ \\
5 & $1.03 \mathrm{a}$ & 1.02 & 0.22 & 0.35 & $0.027 \mathrm{ab}$ & $1233 \mathrm{c}$ \\
10 & $1.44 \mathrm{~b}$ & 1.00 & 0.23 & 0.37 & $0.038 \mathrm{~b}$ & $1102 \mathrm{bc}$ \\
20 & $1.35 \mathrm{~b}$ & 1.14 & 0.24 & 0.35 & $0.057 \mathrm{c}$ & $1040 \mathrm{~b}$ \\
50 & $1.33 \mathrm{~b}$ & 1.11 & 0.25 & 0.41 & $0.068 \mathrm{c}$ & $852 \mathrm{a}$ \\
\hline $\mathrm{LSD}_{0.05}$ & 0.26 & n.s. & n.s. & n.s. & 0.014 & 134 \\
\hline
\end{tabular}

Note: Mean values marked with the same letters are not significantly different at $\mathrm{P} \leq 0.05$ n.s. - not significant

A considerable increase of phenolic compounds content was recorded in leaves of plants treated with the solution containing 3-20 mg Se $\cdot \mathrm{dm}^{-3}$ (Table 1). The highest percentage of total phenols (by $44 \%$ in relation to the control) was 
found in plants sprayed with $5 \mathrm{mg} \cdot \mathrm{dm}^{-3}$ selenium solution. Selenium at the concentrations of 3,10 , and $20 \mathrm{mg} \cdot \mathrm{dm}^{-3}$ caused the increase of phenolic compounds respectively by 17,29 , and $21 \%$ comparing to the control. Both the lowest, and the highest selenium concentrations had not significant effects on phenolic compounds contents in basil's shoots.

Analysis of malonodialdehyde (MDA) - indicator of cell membrane lipid injuries - revealed that its level showed decreasing tendency along with the increase of selenium concentration applied for spraying, as well as with the increase of selenium content in shoot dry matter (Fig. 1). Reduction of MDA content due to selenium concentrations of 10 and $50 \mathrm{mg} \cdot \mathrm{dm}^{-3}$ appeared to be statistically significant, because respectively $34 \%$ and $39 \%$ decrease of MDA levels in relation to controls was recorded.

Foliar selenium application affected the increase of the element in basil's shoots (Fig. 1). In control plants, mean selenium concentration was $0.15 \mathrm{mg} \cdot \mathrm{kg}^{-1}$ DW. After foliar fertilization, total selenium content in shoots increased proportionally to its concentration in the solution and ranged from $0.95 \mathrm{mg} \cdot \mathrm{kg}^{-1}$ DW after application using $1 \mathrm{mg} \mathrm{Se} \cdot \mathrm{dm}^{-3}$ to $150 \mathrm{mg} \cdot \mathrm{kg}^{-1} \mathrm{DW}$ in plants treated with $50 \mathrm{mg} \mathrm{Se} \cdot \mathrm{dm}^{-3}$. No visible foliar injury symptoms were observed on plants treated with selenium by foliar application (Photo 1A-D).

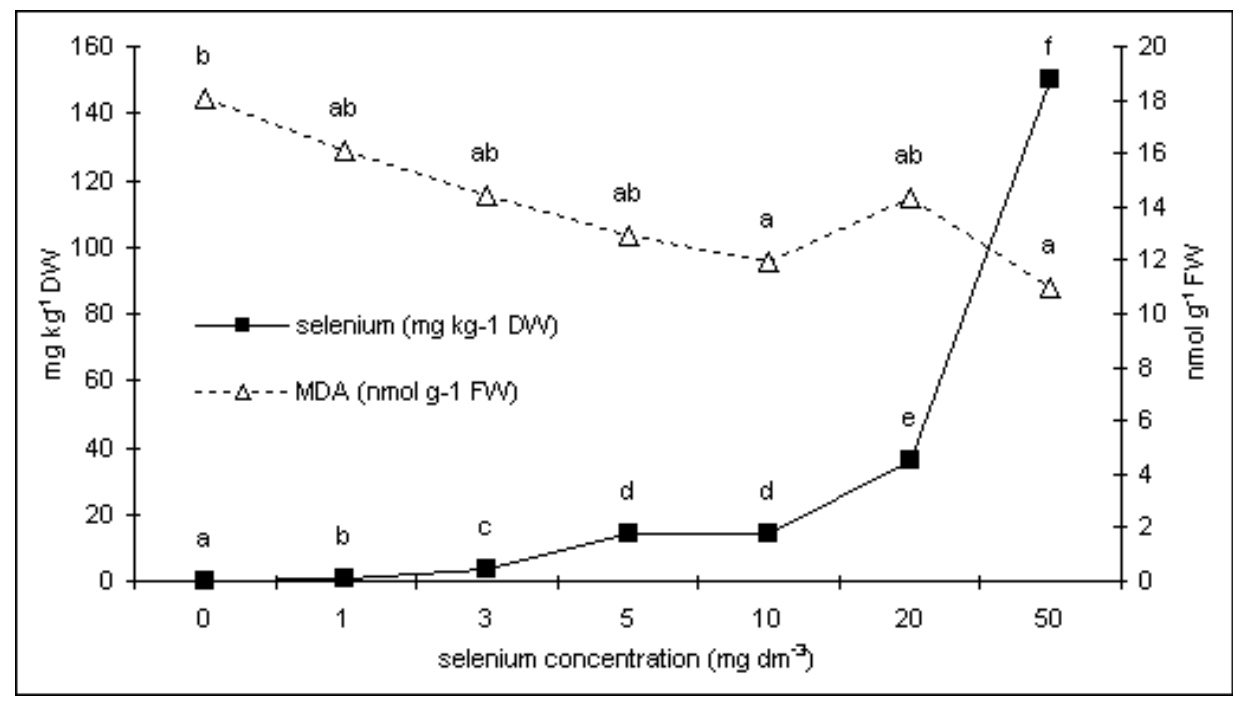

Fig. 1. Influence of selenium foliar fertilization on MDA and total selenium content in sweet basil shoots Note: see Table 1 

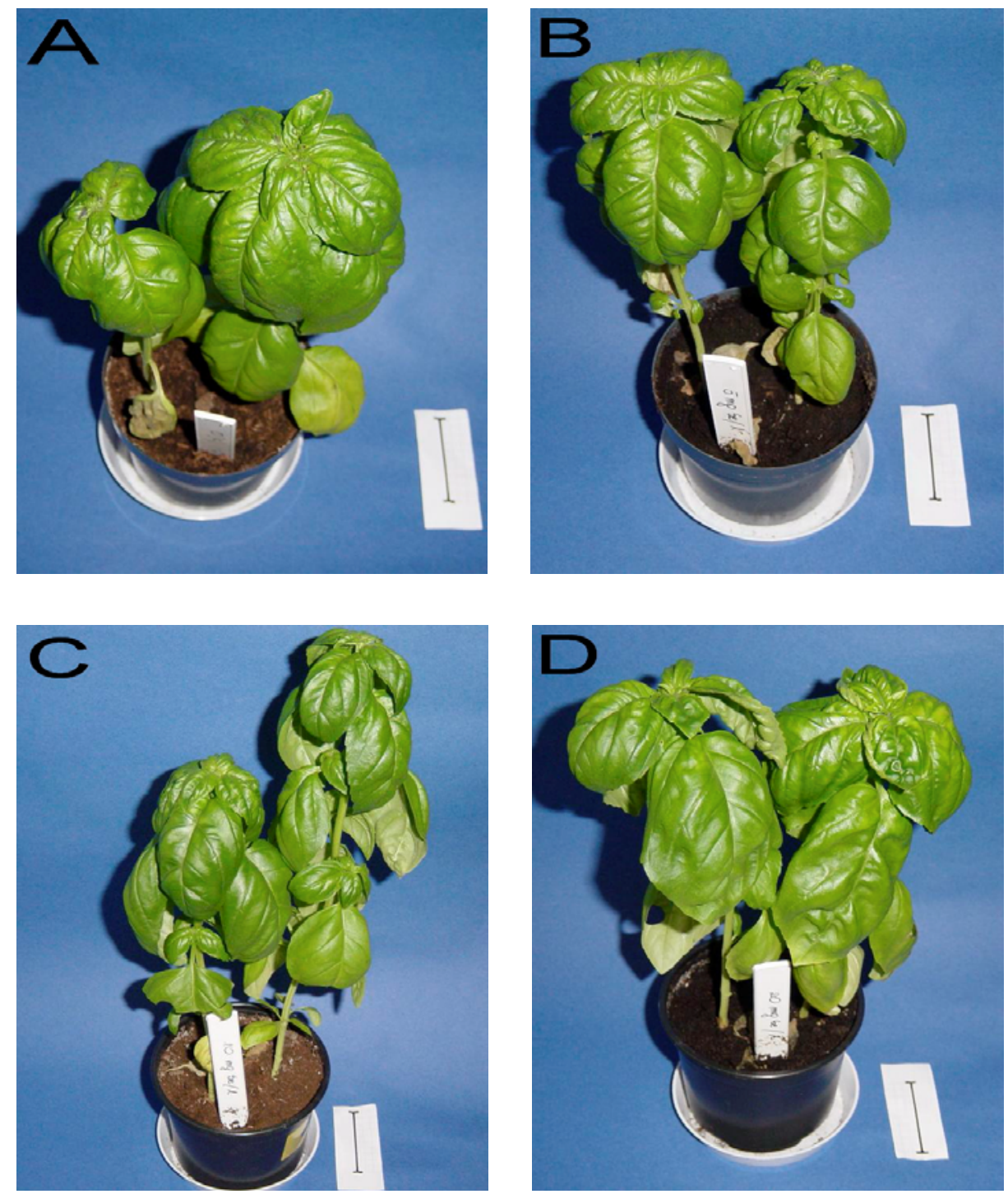

Photo.1. Sweet basil plants one week after foliar application of selenium $\left(\mathrm{mg} \mathrm{Se} \cdot \mathrm{dm}^{-3}\right)$ : A - 0 (control), B - 5, C - 10, D - 20

\section{DISCUSSION}

Due to a selenium influence on numerous metabolic transformations and its low level in Polish diet, it is important to introduce it into the food chain using possibly efficient and safe methods. One of them, that deserves a special interest, is foliar nutrition the crop biomass with the element. Present experiments focused on the selenium contents and selected physiological parameters in basil plants treated sodium selenate by foliar application. 
In higher plants metabolism of selenium is closely related to that of sulfur due to their chemical similarity. It was proposed that selenate, chemically analogous to the sulfate ion, is actively transported via sulfate transporters in cellular membranes, therefore the sulfur presence may affect selenium accumulation and vice versa. Selenium is evidently metabolised via the same enzymes used in sulphur assimilation and can be incorporated into amino acids in the place of sulphur (Terry et al. 2000, Ellis \& Salt 2003).

Sweet basil, as a spice, is often used in a form of dry herb, thus the total selenium content was expressed after recalculating onto a dry matter. That value was $0.15 \mathrm{mg} \cdot \mathrm{kg}^{-1} \mathrm{DW}$ in shoots of control plants. Analysis of selenium content in various foodstuffs produced in Thailand revealed that its level in fresh basil leaves reached $0.30 \mathrm{mg} \cdot \mathrm{kg}^{-1} \mathrm{FW}$ (Sirichakwal et al. 2005), which was much higher than that found in present experiment. The difference probably results from different selenium contents in soils from Poland vs. Thailand. Taking into account the foliar selenium application, it was recorded that the lowest level of applied element contributed to about 6-fold increase of selenium concentration in shoot dry matter. The increase of selenium content in applied spraying solution affected its gradual amounts in basil up to the value of $150 \mathrm{mg} \cdot \mathrm{kg}^{-1} \mathrm{DW}$ in plants treated with $50 \mathrm{mg} \mathrm{Se} \cdot \mathrm{dm}^{-3}$ (Fig. 1). It is worth mentioning that selenium applied in above concentrations did not exert any visual toxicity symptoms in plants (Photo 1A-D). Studies upon the foliar application of selenium for crops being carried out in Slovenia (Stibilj et al. 2004, Germ et al. 2007), Slovakia (Ducsay \& Ložek 2006), and Canada (MacLeod et al. 1998), also indicate a positive influence of that method on selenium content in plant's biomass.

Contents of assimilation pigments in basil leaves was comparable to values recorded for that species by Kopsell et al. (2005), and applied selenium concentrations had not significant influence on their levels (Table 1). Quantities of anthocyanins significantly increased in plants treated with selenium at 10-50 $\mathrm{mg} \cdot \mathrm{dm}^{-3}$ rates. Also total content of phenolic compounds was elevated due to 3$20 \mathrm{mg} \mathrm{Se} \cdot \mathrm{dm}^{-3}$. In plants, the increase of anthocyanin and phenolic compounds levels are frequently recorded as a result of various stress factors (WinkelShirley 2002); however, taking into account the biological activity of anthocyanins and phenols in human's and animal's organisms, their increase in plant biomass seems to be a positive phenomenon.

Although selenium is not at present considered as essential for plants, it is most often introduced into the food chain by means of crops fertilization with selenium salts in areas with its deficits in a diet. Besides advantages associated with foodstuff products enrichment, more and more data also indicate a positive influence of selenium on plants. Probably the first positive effect of this element on plant growth was reported by Singh et al. (1980), who showed that the application of $0.5 \mathrm{mg} \cdot \mathrm{kg}^{-1}$ selenium as selenite stimulated growth and dry matter yield of Indian mustard plants. More recently, it was revealed that low selenium concentrations affect the increase of plant's tolerance towards abiotic stress factors, e.g. UV radiation (Hartikainen \& Xue 1999) or excessive subsoil salinity (Kong et al. 2005). Performed studies proved that dry matter yield of basil 
seedlings treated with $10-50 \mathrm{mg} \mathrm{Se} \cdot \mathrm{dm}^{-3}$ was by $25-35 \%$ higher as compared to control plants (Table 1), which may confirm a beneficial selenium influence on the species growth. It can be also indicated by the decrease of MDA level (Fig. 1). The MDA content is an indicator of cell membrane lipid peroxidation, and its decrease indicates the inhibition of unfavorable process of polyunsaturated fatty acids oxidation and the increase of membranes stability in a cell. The observed growth-promoting response to selenium was similar to that reported for lettuce (Xue et al. 2001), ryegrass (Hartikainen et al. 2000), and soybean (Djanaguiraman et al. 2004). Hartikainen et al. (2000) suggest a dual selenium nature: at low concentrations it can act as an antioxidant and promote plant growth, whereas at higher concentrations it is an prooxidant causing metabolic disturbances and yield losses. Djanaguiraman et al. (2004) propose that increased biomass in Se-treated plants may be attributed to increased photosynthetic rate and better partitioning efficiency of photoassimilates. However, the specific physiological mechanisms that underlie the positive effects of selenium in plants have not been clearly elucidated.

\section{CONCLUSIONS}

It should be concluded that foliar selenium application in a form of sodium selenate may be an efficient way of enriching the sweet basil biomass in that element. Selenates, in a wide concentration range $\left(1-50 \mathrm{mg} \mathrm{Se} \cdot \mathrm{dm}^{-3}\right)$, did not cause plant's injuries and only to a small extent affected the analyzed physiological parameters. At the same time, foliar selenium nutrition made a considerable increase of total selenium content in biomass. It is also worth mentioning that enrichment of herbal plants in selenium does not arise the risk of its overdosing due to a small percentage of herbs in a diet, and it may be a safe and efficient supplementation method.

\section{REFERENCES}

Birringer M., Pilawa S., Flohé L. 2002. Trends in selenium biochemistry. Nat. Prod. Rep. 19: 693-718. [DOI: 10.1039/b205802m]

Boominathan R., Doran P.M. 2002. Ni-induced oxidative stress in roots of the Ni hyperaccumulator, Alyssum bertolonii. New Phytol. 156: 205-215. [DOI: 10.1046/j.1469-8137.2002.00506.x]

Borkowski J., Dyki B. 2007. Nawożenie gleb selenem. pp. 46-53. In: Selen - pierwiastek ważny dla zdrowia, fascynujący dla badacza (M. Wierzbicka, E. Bulska, K. Pyrzyńska, I. Wysocka, B.A. Zachara eds.), Malamut, Poland. [in Polish]

Cheng, G., Breen, P.J. 1991. Activity of phenylalanine ammonia-lyase (PAL) and concentrations of anthocyanins and phenolics in developing strawberry fruit. J. Am. Soc. Hortic. Sci. 116: 865-869.

De Masi L., Siviero P., Esposito C., Castaldo D., Siano F., Laratta B. 2005. Assessment of agronomic, chemical and genetic variability in common basil (Ocimum basilicum L.). Eur. Food Res. Technol. 223: 273-281.

[DOI: $10.1007 / \mathrm{s} 00217-005-0201-0]$ 
Dębski B., Zachara B., Wąsowicz W. 2001. Próby oceny poziomu selenu w Polsce oraz jego wpływu na zdrowotność ludzi i zwierząt. Folia Univ. Agric. Stetin. Zootechnica 224: 31-38. [in Polish]

Djanaguiraman M., Devi D.D., Shanker A.K., Sheeba J.A., Bangarusamy U. 2004. Impact of selenium spray on monocarpic senescence of soybean (Glycine max L.). J. Food Agric. Environ. 2: 44-47.

Ducsay L., Ložek O. 2006. Effect of selenium foliar application on its content in winter grain. Plant Soil Environ. 52 (2): 78-82.

Ellis D.R., Salt D.E. 2003. Plants, selenium and human health. Curr. Opin. Plant Biol. 6: 273-279. [DOI: 10.1016/S1369-5266(03)00030-X]

Germ M., Stibilj V., Osvald J., Kreft I. 2007. Effect of selenium foliar application on chicory (Cichorium intybus L.). J. Agric. Food Chem. 55: 795-798. [DOI: 10.1021/jf0629888]

Giessel-Nielsen G., Gupta U.C., Lamand M., Westermarck T. 1984. Selenium in soil and plants and its importance in livestock and human nutrition. Adv. Agron. 37: 397-460.

Hartikainen H., Xue T. 1999. The promotive effect of selenium on plant growth as trigged by ultraviolet irradiation. J. Environ. Qual. 28: 1272-1275.

Hartikainen H., Xue T., Piironen V. 2000. Selenium as an anti-oxidant and pro-oxidant in ryegrass. Plant Soil 225: 193-200. [DOI: 10.1023/A:1026512921026]

Kong L., Wang M., Bi D. 2005. Selenium modulates the activities of antioxidant enzymes, osmotic homeostasis and promotes the growth of sorrel seedlings under salt stress. Plant Growth Reg. 45 (2): 155-163. [DOI: 10.1007/s10725-005-1893-7]

Kopsell D.A., Kopsell D.E., Curran-Celentano J. 2005. Carotenoid and chlorophyll pigments in sweet basil grown in the field and greenhouse. HortScience 40(5): 1230-1233.

Lichtenthaler H.K., Wellburn A.R. 1983. Determination of total carotenoids and chlorophyll $\mathrm{a}$ and $\mathrm{b}$ of leaf extracts in different solvents. Biochem. Soc. Trans. 603: 591-592.

Lloyd B., Holt P., Delves H.T.. 1982. Determination of selenium in biological samples by hydride generation and atomic-absorption spectroscopy. The Analyst 107: 927933. [DOI: 10.1039/AN9820700927]

MacLeod J.A., Gupta U.C., Milburn P., Sanderson J.B. 1998. Selenium concentration in plant material, drainage and surface water as influenced by Se applied to barley foliage in a barley - red clover - potato rotation. Can. J. Soil Sci. 78: 685-688.

Martinez A.E., Favret E.A. 1990. Anthocyanin synthesis and lengthening in the first leaf of barley isogenic lines. Plant. Sci. 71: 35-43. [DOI:10.1016/0168-9452(90)90066-W]

Poggi V., Arcioni A., Filippini P., Pifferi P.G. 2000. Foliar application of selenite and selenate to potato (Solanum tuberosum): effect of a ligand agent on selenium content of tubers. J. Agric. Food Chem. 48: 4749-4751. [DOI: 10.1021/jf000368f ]

Rayman M.P. 2000. The importance of selenium to human health. The Lancet 356: 233241. [DOI:10.1016/S0140-6736(05)73928-3]

Singh M., Singh H., Bhandari D.K. 1980. Interaction of selenium and sulphur on the growth and chemical composition of raya. Soil Science 129: 238-244.

Sirichakwal P.P., Puwastien P., Polngam J., Kongkachuichai R. 2005. Selenium content of Thai foods. J. Food Comp. Anal. 18: 47-59. [DOI: 10.1016/j.jfca.2003.10.010]

Stibilj V., Kreft I., Smrkolj P., Osvald J. 2004. Enhanced selenium content in buckwheat (Fagopyrum esculentum Moench) and pumpkin (Cucurbita pepo L.) seeds by foliar fertilisation. Eur. Food Res. Technol. 219: 142-144.

[DOI: 10.1007/s00217-004-0927-0] 
Swain T., Hillis W.E. 1959. The phenolic constituents of Prunus domestica. I. The quantitative analysis of phenolic constituents. J. Sci. Food Agric. 10: 63-68.

[DOI: 10.1002/jsfa.2740100110]

Terry N., Zayed M., De Souza M.P., Tarun A.S. 2000. Selenium in higher plants. Ann. Rev. Plant Physiol. Plant Mol. Biol. 51: 401-432. [DOI: 10.1146/annurev.arplant.51.1.401]

Winkel-Shirley B. 2002. Biosynthesis of flavonoids and effects of stress. Curr. Opi. Plant Biol. 5: 218-223. [DOI: 10.1016/S1369-5266(02)00256-X]

Xue T., Hartikainen H., Piironen V. 2001. Antioxidative and growth-promoting effect of selenium in senescing lettuce. Plant Soil 237: 55-61.

[DOI: 10.1023/A:1013369804867]

\section{WZBOGACANIE W SELEN BIOMASY BAZYLII (OCIMUM BASILICUM L.) PRZEZ NAWOŻENIE DOLISTNE}

Selen jest pierwiastkiem śladowym niezbędnym dla ludzi i zwierząt. Chociaż dotychczas nie został uznany za niezbędny mikroelement $\mathrm{w}$ tkankach roślinnych, rośliny pełnią ważną rolę w procesie jego obiegu w przyrodzie wprowadzając selen $\mathrm{z}$ gleby do łańcucha pokarmowego. Celem prezentowanych badań było określenie wpływu dolistnego nawożenia selenem stosowanym w stężeniach od 1 do $50 \mathrm{mg} \mathrm{Se} \cdot \mathrm{dm}^{-3}$ na wzrost siewek, zawartość: barwników asymilacyjnych, antocyjanów, związków fenolowych ogółem oraz selenu, jak również poziom peroksydacji lipidów w roślinach bazylii (Ocimum basilicum L.). Wykazano, że całkowita zawartość selenu w częściach użytkowych bazylii wzrastała wraz ze wzrostem stężenia selenu w stosowanym do oprysku roztworze. Nie stwierdzono istotnego wpływu nawożenia selenem na zawartość barwników asymilacyjnych, wzrastała natomiast synteza antocyjanów i związków fenolowych. Poziom MDA (dialdehydu malonowego) w liściach bazylii spadał wraz ze wzrostem stężenia selenu w roztworze stosowanym do oprysku. Uzyskane wyniki wskazują na możliwość wzbogacania biomasy bazylii w selen poprzez nawożenie dolistne. Bazylia o wyższej zawartości selenu może być cennym źródłem tego pierwiastka i użytecznym surowcem służącym wzbogacaniu w selen produktów żywnościowych. 